\title{
MIR214 Gene
}

National Cancer Institute

\section{Source}

National Cancer Institute. MIR214 Gene. NCI Thesaurus. Code C81755.

This gene is involved in the regulation of gene expression and plays a role in the development of ovarian carcinoma. 